\title{
Analysis of Mobile Commerce Value Chain
}

\author{
Yan Wang and Tingjie Lu \\ School of Economics \& Management, Beijing University of Posts \& Telecommunications, \\ Beijing 100876, P.R. China wangyan.bupt@gmail.com lutingiie@263.net
}

\begin{abstract}
The opportunities offered by the Internet have already fuelled immense growth of E-commerce. In recent years, due to the rapid evolution of wireless and mobile communication technologies, mobile commerce becomes another crucial application. In china, the $3 G$ telecommunication era is coming. As to the brilliant prospect for $m$-commerce, many industries expect to join this arena. The mobile commerce value chain is then formed. This paper analyses the major players and technologies that form part of the M-commerce value chain. Also it figures out that mobile telecommunication operators are the most crucial members on this value chain. As a result, this paper attempts to investigate the challenges for mobile telecommunication operators and described that the operators must adopt the innovation strategies to unleash the potential of the value chain.
\end{abstract}

Keywords: Application, Mobile commerce, Network operator, Two-sided markets, Value chain

\section{INTRODUCTION}

With the prevalence of the Internet, electronic commerce (E-commerce) has achieved significant success in the last few years. A confluence of technological leaps in devices, networks, and applications is setting the stage for wireless to change our lives. According to the China Information Industry Ministry's survey, mobile phone subscribers in China are estimated to be around 459 million by the end of 2007 . The wireless voice market is becoming saturated and the network operators attempt to increase the value-added service income. With the wireless network moving toward the third generation (3G), mobile commerce as known as M-commerce will become one of the most promising growth markets.

E-commerce is considered to be the buying and selling of information, products and services via computer networks. $\mathrm{M}$-Commerce is basically any $\mathrm{E}$-commerce done in a wireless environment $\mathrm{M}$-commerce can be defined as any transaction with a monetary value either direct or indirect that is conducted over a wireless telecommunication network. The major characteristics of M-Commerce are mobility and broad reach.

The paper is structured as follows. In section 2, we mention the emerging mobile commerce applications and discuss the $\mathrm{M}$-commerce related technologies. Section 3 defines the M-commerce value chain and catalogs the members of it. In section 4 , we 
discuss the roles of mobile network operators on this value chain and the key issues faced by the operators. Section 5 concludes the paper with a brief summary.

\section{APPLICATIONS AND TECHNOLOGIES SUPPORT}

\subsection{Emerging Mobile Commerce Applications}

Since there are potentially unlimited M-commerce applications, we attempt to identify several important classes of applications. Varshney and Vetter have identified twelve classes. Table 1 shows these classes and the example applications [1].

Table 1. Mobile Commerce Applications and Examples

\begin{tabular}{|c|c|}
\hline Class of applications & Examples \\
\hline Mobile financial applications & Banking, brokerage, and payments for mobile users \\
\hline Mobile advertising & User specific and location sensitive advertisements \\
\hline Mobile inventory management & $\begin{array}{l}\text { Location tracking of goods, boxes, troops, and } \\
\text { people. }\end{array}$ \\
\hline Produce locating and shopping & $\begin{array}{l}\text { Finding the location of new/used car of certain } \\
\text { model, color and features. }\end{array}$ \\
\hline Proactive service management & $\begin{array}{l}\text { Transmission of information related to aging } \\
\text { (automobile) components to vendors }\end{array}$ \\
\hline Wireless re-engineering & Instant claim-payments by insurance companies \\
\hline $\begin{array}{l}\text { Mobile auction or reverse } \\
\text { auction }\end{array}$ & $\begin{array}{l}\text { Airlines competing to buy a landing time slot during } \\
\text { runway congestion (a proposed solution to air-traffic } \\
\text { congestion problem). }\end{array}$ \\
\hline $\begin{array}{l}\text { Mobile entertainment services } \\
\text { and games }\end{array}$ & $\begin{array}{l}\text { Video-on-demand, audio-on-demand, and interactive } \\
\text { games. }\end{array}$ \\
\hline Mobile office & Working from traffic jams, airport, and conferences. \\
\hline Mobile distance education & Taking a class using streaming audio and video. \\
\hline Wireless data center & $\begin{array}{l}\text { Detailed information on one or more products can be } \\
\text { downloaded by vendors. }\end{array}$ \\
\hline
\end{tabular}

\subsection{Technologies Support}

M-commerce applications require the support of technologies from the foundation of wireless user infrastructure, mobile middleware, and wireless network infrastructure [1].

- Network technology: Wireless network infrastructure provides wireless net-work and network standards such as GSM, Blue-tooth, WLAN, RFID, 3G network, etc. M-commerce's requirement on the wireless infrastructure includes location management, multicast support, network dependability, Quality-of-Service, and roaming across multiple networks. 
- Mobile middleware technology: Mobile middleware refers to the software layer between the wireless networks and the operating system of the mobile devices to connect the M-commerce applications. Typically, network enabled middleware uses optimization techniques, such as header compression, delayed acknowledgements, and concatenation of several smaller packets into one, to reduce the amount of traffic on the wireless networks. Middleware becomes very important due to the potential values of many M-commerce transactions, limited capabilities of devices, and diverse set of requirements presented by various applications.

- User infrastructure technology: Wireless user infrastructure consists of software and hardware. Software refers to the operating systems and the interfaces while hardware means the mobile devices, such as mobile phones and PDAs. Many handheld devices now support a varity of network interfaces and access ranges. Location support, video streaming, barcode readers and other features are also being implemented in many of the devices. Handheld devices are likely to affect the interoperability, implementability, and scalability of M-commerce applications as well.

\section{THE MOBILE COMMERCE VALUE CHAIN}

\subsection{The Definition of Mobile Commerce Value Chain}

Value chain is the linkage and integration of a series of activities in which enterprises deliver the created and valued products or services to customers. Porter pointed out the value chain of enterprises is essentially encompassed in a broader value system. This value system is the so-called industry value chain, and is also pertaining to the value chain discussed in this study [2].

Like any product or service, $\mathrm{M}$-commerce involves a number of players in a chain of value-adding activities that terminates with customer. Mobile commerce value chain is essentially the aggregation of the conventional mobile communication value chain and the Internet value chain [3,4]. To deliver mobile value, the mobile commerce value chain is evolving into a set of partnership [5].

\subsection{The Members of Mobile Commerce Value Chain}

By understanding the roles of all players and how they come together to offer data service value to subscribers, we can explore the partnerships among them. The participating members can be generally categorized as in Table 2 . 
With the complexity of interactions among the players increasing, market turning competitive, the value chain is evolving into a set of partnerships to deliver value. To win the customers' perception of mobile commerce service, the operators must cooperate with the other roles in this value chain [6].

Table 2. Mobile Commerce Applications and Examples

\begin{tabular}{|l|l|}
\hline Members & The role of members \\
\hline $\begin{array}{l}\text { Mobile network } \\
\text { operators }\end{array}$ & To Provide mobile communication networks. \\
\hline Service providers & $\begin{array}{l}\text { To aggregate, integrate, re-packaging or distributing products or } \\
\text { services related to consumers, such as news, games, and financial } \\
\text { messages }\end{array}$ \\
\hline Content providers & $\begin{array}{l}\text { To provide, design or producing various kinds of products or } \\
\text { services necessary to all kinds of consumers }\end{array}$ \\
\hline $\begin{array}{l}\text { Application } \\
\text { providers }\end{array}$ & $\begin{array}{l}\text { To convert all kinds of Internet-based applications into the } \\
\text { wireless environment, and develop application software to enrich } \\
\text { the compass and content of mobile applications }\end{array}$ \\
\hline $\begin{array}{l}\text { Infrastructure and } \\
\text { mobile equipment } \\
\text { vendors }\end{array}$ & $\begin{array}{l}\text { To design and manufacture communication network as well as } \\
\text { mobile handset or other equipment that support WAP, GPRS, } \\
\text { 3G, Wi-Fi or other communication technologies. }\end{array}$ \\
\hline $\begin{array}{l}\text { Middleware } \\
\text { provider }\end{array}$ & $\begin{array}{l}\text { To provide pre-built components, including wireless middleware } \\
\text { and application middleware to consumers or enterprise }\end{array}$ \\
\hline $\begin{array}{l}\text { Mobile equipment } \\
\text { retailers }\end{array}$ & $\begin{array}{l}\text { To sell all kinds of mobile equipments or retailing-related } \\
\text { products to consumers }\end{array}$ \\
\hline Customer & End-users, including general consumers or enterprise users \\
\hline
\end{tabular}

\section{ISSUES FOR MOBILE NETWORK OPERATORS}

In the past years, the voice service is the main service of the mobile network operators. Traditionally, the telecommunication operators managed and owned the entire value chain. The mobile network operators do not owned the entire value chain of mobile commerce but they still have a dominant position in the value chain.

Telecommunication operators can play a very active and important role in the $\mathrm{M}$ commerce services because the users must go through their networks to perform all mobile commerce transactions. Moreover, the operators can provide users one common bill (bundled services) for voice, data, and mobile commerce services. Although they may play any of the other roles, they choose not to play all the roles but still focus on their core business [7].

Many markets where network externalities are important are, in fact, two-sided markets. Two-sided markets are roughly defined as markets in which one or several platforms enable interactions between users, and try to get the two sides "on board" by appropriately charging each side. The mobile commerce service is also two-sided markets [8]. 
The value chain coordination and the suitable price policy become the present issues of the mobile data service markets. A key aspect of the business model for firms operating in two-sided markets involves the optimal pricing structure: the division of revenues between the two sides [8].

\section{CONCLUSIONS}

The development of technologies has fuelled the rapid growth of mobile commerce services. Telecommunication Operators play an important role on the evolving value chain. Their main advantages rest with the ownership of the network infrastructure, their technical know-how and understanding of mobile features, and their control of the billing interface with customers. As we move into more complex m-commerce services the operator's dominant positions may be challenged.

The mobile commerce service is a type of two-sided market. A key aspect of the business model for firms operating in two-sided markets involves the optimal pricing structure: the division of revenues between the two sides. Platform owners must address the celebrated "chicken-and-egg problem" and be careful to "get both sides on board". The value chain coordination and the suitable price policy become the present issues of the mobile commerce service markets.

\section{REFERENCES}

1. U. Varshney and R. Vetter, Mobile commerce: framework, applications and networking support, Mobile networks and Applications. Volume 3, Number 7, pp.185-198, (2002).

2. M.E. Porter, Competitive Advantage: Creating and sustaining Superior Performance (The Free Press: NY, 1985).

3. H.W. Kim, H.C. Chan, and S. Gupta, Value-based Adoption of Mobile Internet: An empirical investigation, Decision Support Systems. Volume 43, pp.111-126, (2007).

4. G. Lundberg and A. Zucker, Wireless data services: Mobile Internet report Morgan Stanley Dean Witter, 2006), p.44.

5. H.K. Sabat, The evolving mobile wireless value chain and market structure, Telecommunication Policy. Volume 26, pp.505-535, (2002).

6. S.J. Barnes, The mobile commerce value chain: analysis and future developments, International Journal of Information Management. Volume 22, pp.91-108, (2002).

7. Y. Kuo and $\mathrm{C}$. $\mathrm{Yu}, 3 \mathrm{G}$ telecommunication operators' challenges and roles: A perspective of mobile commerce value chain, Technovation. Volume 26, Number 12, pp.1347-1356, (2006).

8. J. Rochet and J. Tirole, Defining two-sided markets, working paper (Mimeo, IDEI, Universite de Toulouse, 2004). 